\title{
Design of Mosque Ablution Areas for Disabled: Evaluation of Ministerial Regulation of Public Works and Public Housing No. 14/2017
}

\author{
Rinaldy Yumadhika ${ }^{1}$, Arif Budi Sholihah' \\ 1 Student of the Master of Architecture, Universitas Islam Indonesia,
Yogyakarta
2 Lecturer of the Master of Architecture, Universitas Islam Indonesia,
Yogyakarta
}

Article History

Received : 09 May 2019

Accepted : 02 July 2019

Published : 01 October 2019

\begin{abstract}
Equality for disabled is regulated in Indonesia including the right to embrace religion, to access, and to use worship facilities. Disabled in Indonesia still becomes a minority group even though the number of disabled is considerably large. The Province of Special Region of Yogyakarta is ranked second as the highest number of disabled, the high number of people with disabilities should be directly proportional to the providing of disability-friendly worship facilities. Ablution area is one of the facilities that the presence is very much needed to cleanse ourselves before performing worship. This study aims to determine the elements that affect the accessibility of the ablution area for the disabled and to recommend a design that has been considered with the ability of the disabled. This study uses a qualitative method with a naturalistic approach, which is following the existing conditions toward a case study of the Great Mosque of Manunggal Bantul. Data collection is conducted by simulating the access to ablution area by the disabled and expert interviews, which are architects to help researchers produce a design that is disabled-friendly, the validity of the data is done by triangulation between the simulation results and the results of expert interviews compared to the Ministerial Regulation of Public Works and Public Housing No. 14/2017. Simulation results that are followed by expert interviews show several elements that affect the accessibility of the ablution area: ramp, steering tile, handrail, information on space, stair, chair for ablution, faucet, grill, floor material, and place of good. Comparative results of the regulations show that some elements that have not explained yet about the ablution area that is disabled-friendly, the regulation only describes the ablution area for the disabled by sitting with and without wheelchair equipped with handrails. Recommended designs are ramp, directional tile, handrail, room information, stair, chair for ablution, faucet, grill, floor surface, and items that have been considered with disability.
\end{abstract}

Keywords: accessibility, differential disabled, ablution area, ablution, ministerial regulation

\section{Introduction}

The number of disabled people in Indonesia reaches $6,515,500$ people, the top type of disabled is more than one type of disability and then followed by disabled people with limited vision, and walking or climbing stairs. Special Region of Yogyakarta is the second province

Correspondence: Rinaldy Yumadhika

Student of the Master of Architecture, Universitas Islam Indonesia, Yogyakarta

E-mail:16922001@students.uii.ac.id after Bengkulu Province with the highest number of disabled according to the Indonesia's Central Bureau of Statistics (BPS) based on the data from the National Socio-Economic Survey in 2012 (Kementrian Kesehatan RI, 2014).

Equality rights in Indonesia apply to all groups of people including the disabled who are free to embrace religion, politics, socials, and economics. The equality right began to be regulated in the preamble of the 1945 Constitution which stated justice for all Indonesians. The Law on Persons with Disabilities stated the obligation of the 
Government and Regional Governments to protect Persons with Disabilities from discrimination and pressure, and is clarified with several other regulations such as the Minister of Public Works Regulation on Technical Guidelines for Facilities and Accessibility in Buildings and Environments, the Law on Human Rights, the Minister of Social Affairs Regulation on the Habilitation Standards and Social Rehabilitation of Persons with Disabilities, the Law on Social Welfare, the Law on Building, and other regulations. The regulations above should be able to support disabled activities in order to enable them to use and access public facilities appropriately.

In Indonesia, Islam is the majority religion of where the followers reach 07,176,162 people, or $87.2 \%$ of the total population in Indonesia (Central Bureau of Statistics (BPS), 2010). Muslims in Indonesia also have quite a number of worship places in the form of mosques, which are around 900,000 mosques (Tribunnews.com, 2017). Mosque typologies include State Mosque, Akbar Mosque, Great Mosque, Grand Mosque, Raya Mosque, Big Mosque, Historical Mosque, and Mosque in public places (Direktorat Jenderal Bimbingan Masyarakat Islam, 2014). This number is the potential of whether existing places of worship have supported the ability of people with disabilities to access places of worship.

"[1] The Prophet (Muhammad) frowned and turned away, [2] Because there came to him the blind man, [interrupting]." (The Qur'an 'Abasa 80:1-2)

The chapter of 'Abasa was revealed by Allah SWT as a form of Allah's reprimand to the Messenger of Allah SWT because he had ignored the interests or needs of a blind person with disabilities. According to history, the Prophet was discussing with a Quraysh leader who was expected to convert to Islam, and there came Ibn Ummi Maktum, a friend who was blocked from sight (blind) who wanted the Prophet to recite the holy verses of the Qur'an, but the Messenger of Allah turned away from this blind friend. It can be concluded from the above event that we should not discriminate against one's physical condition and respect any interests of humanity.

\section{State of the Art}

Studies that discuss accessibility for disabled are done by a lot of researchers starting from Keumala (2016), her study discusses about the universal design of the level of independence of disabled with case study of the Sunan Kalijaga State Islamic University campus mosque and the Gadjah Mada University campus mosque from entrance/exit door, corridor, ramp, stair, handrail, ablution area, toilet, prayer room, parking area, as well as sign and information. The results of observation indicate that the Sunan Kalijaga State Islamic University campus mosque has applied the concept of universal design or its level of independence by $76.19 \%$ which is better compared to Gadjah Mada University campus mosque. Sholihah (2008), comparing the three mosques related to accessibility in the Kauman Gedhe Mosque, the Syuhada Mosque, and the Assa'adah Mosque, the method used was a simulation performed by wheelchair users, the visually impaired, and crutch users, in order to identify obstacles faced by disabled. The results of the study explain the Assa'adah Mosque as a mosque that is relatively easily accessible compared to other mosques, but that does not mean that the Assa'adah Mosque should be an accessible mosque model. Suhardi, Laksono, \& Saktiwan (2013), discussed the ablution place for the elderly that was conducted at the Dharma Bhakti Nursing Home, Surakarta. This study aims to produce a design of ablution places that have been considered with the ability of the elderly.

The above studies discuss the accessibility of the disabled in several mosques in general and there is a research that discusses the ablution in detail but specifically for the elderly, this study aims to discuss and continue previous researches related to the accessibility of the disabled but specifically in the area of ablution, the method used involves the disabled (user) as performed by Sholihah in her research, the aim is to identify the needs and complaints of disabled people in order to design ablutionfriendly areas for the disabled.

It is concluded that problem formulations of this research are what kind of elements that affect the accessibility of mosque's ablution area for the disabled, and how the design of ablution area that is disabled-friendly and compares it 
to regulations or standards, which is Minister of Public Works and Public Housing Regulation No. $14 / 2017$.

The purpose of this study is to determine the elements that affect the accessibility of ablution areas for the disabled, to design the ablution area with accessibility considerations for the disabled, and to evaluate and to compare the design result with the standards stated in the Minister of Public Works and Public Housing Regulation No. 14/2017.

The limitations of this study include disabilities with visual impairment (blindness) and body disorders consisting of wheelchair and crutch users, the scope of this research area is only in the area of ablution, which is the space before entering the ablution area (transitional space) and ablution room itself, the mosque typology from one of the grand mosques or the great mosque in the Special Region of Yogyakarta, and lighting in the ablution area that is not included in the scope of this study.

\section{Literature Study}

Differential disable (or disabled) is someone who has physical, mental, sensory or intellectual limitations for an indefinite period of time (Republik Indonesia (UU tentang Penyandang Difabilitas), 2016). The types of disability in this study were determined based on a person experiencing physical and sensory impairments as follows:

- Abnormalities of the body, a person who experiences movement disorders due to abnormalities in bone and neuro-muscular structures or the inability of the nervous system and muscles in the body to work as they are supposed to.

- Sense impairment of vision (visual impairment), a person who has impaired or impaired vision. Someone who has a hearing loss (hearing impairment) and someone who has an impairment in speaking is not an obstacle to access the area of ablution. Someone who has normal consciousness does not experience mental disorders, and has a healthy mind is also not an obstacle to be able to worship more specifically to perform ablution activities.

Regulation of the Minister of Public Works and
Public Housing Number 4 of 2017 requires that buildings must be easily accessible to building users including persons with disabilities from outside or inside buildings, along with the complete facilities and infrastructure to support the use of buildings (Ministerial Regulation of Public Works and Public Housing, 2017). The following is a discussion that supports accessibility in these regulations:

- Body movement, regulating or providing guidance so that the planning of a space pays attention and adapts to the size of human body movements, in order to support the building so that it can be used easily, comfortably, safely, and can be accessed independently, thus explaining disability of body movements.

- Placement and Size of Equipment, to support the accessibility of disabled people in buildings, it is explained that the placement of equipment is easily accessible and can make it easier to operate in the form of door handles, window position, placement and size of equipment, handrails on doors, and the size of a wheelchair.

- Corridor Room, explained in the form of corridor space dimensions required for wheelchair users. There are various corridor widths explained, including corridors for access to 1 wheelchair user, 2 wheelchair users, up to 1 wheelchair user plus 1 person with normal physical walking, to explain the free space needed by wheelchair users when going through the corridor and doors.

- Guiding block (guiding block), there are 2 guiding tiles namely warning tiles (texture of dots) and guiding tiles (texture of lines), clarified with the arrangement of guiding tiles for intersections and turns, and explaining the placement of warning tiles for stairs. This explanation can be used as a guide to design an area/space that responds to the ability of the blind.

- Handrail, Handrail is divided into 2 types in this ministerial regulation, there are handrails that rest on the wall and handrails that rest directly on the floor. The regulation also explains that the length of the handrail should exceed the length of the ladder for at least $30 \mathrm{~cm}$, the handrail can be designed to respond to the needs of the blind by placing 
braille letters on the handrail to make it easier for the blind to get information and direct them to the destination.

- Stair, it is recommended that the staircase design does not harm feet when stepping and the steps are equipped with step nosing so that they do not slip easily. The design supports the blind to easily access the stairs even though they have vision problems without worrying about tripping or slipping.

- Ramp, explained that the ramp used as a guide in designing is ramp that has a maximum slope of $1: 10$ for ramp inside the building, and 1:12 for ramp outside the building. If the length of the ramp exceeds 9 meters, it needs to be bordered as a stop area for a moment, the ramp should be equipped with a minimum of $10 \mathrm{~cm}$ high canstein as protection to prevent it from getting out of the ramp path. The regulation also explains the ramp relationship with the entrance/exit, then in front of the door a floor with a flat surface is needed first then connected with the ramp.

- Prayer Room, explained related to the layout of the prayer room which is divided into two zones, which are the prayer room for men and women, as well as the ablution area, and the toilet. The explanation in the form of a picture contained in the regulation illustrates that disabled wheelchair users can access the toilet; it does not yet explain how to access other rooms besides the toilet.

- Ablution places, annex III explains that places of worship in the form of mosques or prayer rooms must be equipped with ablution rooms with the following conditions: ablution rooms are separated between men and women, separate ablution rooms with toilets or bathrooms, use of coarsetextured materials, not slippery and easy to clean for ablution room floors, users and visitors of the building can easily and safely access the ablution room, the faucets in the ablution room are $80 \mathrm{~cm}$ to $100 \mathrm{~cm}$ with a faucet height of $80 \mathrm{~cm}$ to $100 \mathrm{~cm}$ similar to the book "Standards for Design of Ablution and Mosque Spatial Planning" (Suparwoko, 2016). The other additional fixtures that can be provided in the area of ablution in the form of benches, footrests, places to put items, hangers, and mirrors. The regulation also explains that if there is a different floor height between the prayer room and the ablution room, a ramp can be provided to facilitate wheelchair user access.

- Signs and Markings, the placement of signs and markers is explained so that they are easily known or read in relation to the perspective of the disabled, the set of viewpoints does not exceed $30^{\circ}$ of the direction of the eye looking up and down, as well as regulating the size of the letters for the reading distance of a sign and markers.

\section{Method}

This study uses a qualitative research method that can be interpreted as a method for examining the condition of natural objects carried out by researchers as key instruments with a naturalistic approach as is (Sugiyono, 2010). Creating a relationship between the observer and the observed object or phenomenon with no dividing distance so the relationship between the two is interactive.

The Raya Mosque or the Great Mosque in Special Region of Yogyakarta was chosen as the research location. Before conducting the core of the research, the researchers first observed in each mosque to find out which mosque was the least accessible or most difficult to access for the disabled, the purpose was to obtain as much information as possible related to the needs of the disabled in the area of ablution.

Simulation is an attempt to imitate the action or behavior of an activity by pretending (Echols \& Hassan, 2014). The simulation aims to feel the existing conditions as a more concrete form of learning over the ablution area in the mosque. Simulation is exhibited by the disabled and someone with normal physic (researcher) who seems to be disabled, trying to access the ablution area from the transition space can be in the form of a hallway toward the ablution room.

The next stage is data collection techniques through expert interviews conducted by researchers by asking questions and discussions with respondents related to the research to obtain the information needed (Sugiyono, 2014). This method is used to strengthen and evaluate data from simulation 
results to avoid the unilateral meaning of the researcher. The nature of expert or professional group to become a compatible respondent is to have the same or homogeneous field of expertise. The expertise mentioned is the expertise in the field of architecture, more specifically a person who works as an architect and has an Associate Architect license by the Indonesian Architects Association.

The validity of the data carried out by triangulation is a method for studying phenomena to maintain the objectivity and validity of the data by comparing several interrelated data from different perspectives and perspectives (Sugiyono, 2013). The three data are derived from the simulation results, the results of expert interviews, and regulations or standards related to the area of ablution.

\section{Discussion and Result}

Researchers conducted observations at several Great Mosque and Great Mosque in the Province of Special Region of Yogyakarta which consists of one Great Mosque and six Great Mosques, one of which was chosen to be the location of the study, the following observations made by researchers:

Great Mosque of Dr. Wahidin Soedirohoesodo in Sleman, the ablution area has been equipped with ramp and handrail, the floor has a nontextured surface and a bit slippery, the entrance of the ablution area has been equipped with a handrail as a handle but there is a floor washbasin causing a floor difference that will inhibit the disabled especially wheelchair users, where ablution already has two position choices, which are sitting and standing.

The Great Mosque of Syuhada in Yogyakarta City, there is a difference in floor height between the yard and the ablution area as well as the mosque with the ablution area, the difference in floor height is linked to the stairs and there is no other access option in the form of a ramp. The surface of the floor is textured to reduce slippery when the floor is wet, the wall is not equipped with a handrail as a handle for steering and building safety. There are two choices of ablution place outside and inside the building, indirectly the place of ablution outside the building is more easily accessed because it does not have a difference in floor elevation, the choice of ablution is available only for one position that is standing there is no choice of ablution with a sitting position.

The Kauman Gedhe Mosque (Raya) in the city of Yogyakarta, the area of ablution and the mosque is connected but divided into common stepping path and clean stepping path that cause differences in floor height, and the difference in floor height is not connected with ramp or anything else. The surface of the floor is textured to reduce slippery when the floor is wet, the wall is not equipped with a handrail as a handle for steering and building safety. Ablution places that are available already have two choices of position: sitting and standing.

The Manunggal Grand Mosque in Bantul, the ablution area and the mosque are connected by the direction of the path as the footing or sacred boundary and there is a washbasin which causes a difference in floor height and will make it difficult for people with disabilities especially wheelchair users and visually impaired when accessing. The surface of the floor is textured to reduce slippery when the floor is wet, however, the wall is not equipped with a handrail as a handle for steering and building safety. Ablution places are also available only for one position that is standing, there is no choice of ablution with a sitting position. There is a ramp that connects the yard to the ablution area but it is far from the standard because the slope is very steep.

Pengasih Great Mosque in Kulonprogo, there is a difference in floor height between the mosque and the ablution area that is not connected with a ramp. The surface of the floor is textured to reduce slippery when the floor is wet, but the wall is not equipped with a handrail as a handle for steering and building safety. Ablution places are also available only for one position that is standing, there is no choice of ablution with a sitting position.

Kulonprogo Great Mosque, there is a difference in floor height between the courtyard and the mosque with the ablution area that is not connected with a ramp. The entrance area of the ablution area has a handrail as a handle, but there is a washbasin causing a floor difference that will make it difficult for the disabled, especially wheelchair users and visually impaired when they want to access. The surface of the floor is textured to reduce 
slippery when the floor is wet, however, the wall is not equipped with a handrail as a handle for steering and building safety. Ablution places are also available only for one position that is standing, there is no choice of ablution with a sitting position.

Al-lkhlas Great Mosque in Gunung Kidul, there are differences in floor height between the mosque and the ablution area as well as the courtyard of the mosque and the ablution area, the difference in floor height is connected by stairs because the ablution area is under the prayer room floor and there are no other access options. The surface of the floor is textured to reduce slippery when the floor is wet, but the wall is not equipped with a handrail as a handle for steering and building safety. Ablution places are also available only for one position that is standing, there is no choice of ablution with a sitting position.

Figure 1. Ablution Area Great Mosque Manunggal

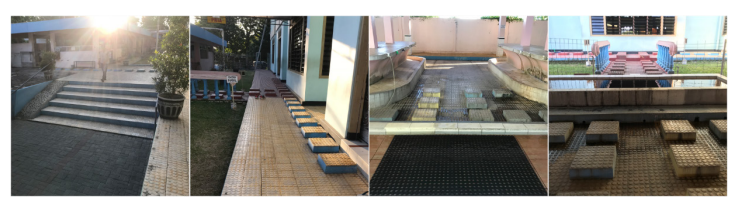

The result of observations can be concluded that the mosque which is the least accessible is the Manunggal Great Mosque in Bantul so that the mosque becomes the choice to conduct a research. Several considerations are including the ablution area is difficult to access due to some differences in floor height, ramp with very steep slope, washbasin which causes differences the height of the floor, and what causes the most inaccessibility is the directional path, as a foothold (holy area) that is alternating so that the disabled such as the visually impaired and physically disabled will find it very difficult to access the mosque ablution area.

\section{Simulation}

Simulations are carried out to explore data related to the needs and complaints of disabled people in accessing the ablution area. The simulation was conducted by the visually impaired as a respondent $A$, physically disabled crutch users as a respondent $B$, wheelchair users as a respondent $\mathrm{C}$, and researchers act as if disabled.
The results of simulations and interviews with the visually impaired and researchers as if visually impaired require information that explains the existence of the ablution area, especially when the visit is conducted is prime. The following are suggestions from respondent A and researchers: a) Spatial information in the form of braille is a way to convey information to the visually impaired. The spatial information should be positioned near the entrances or on the handrail. b) Guiding block, this guiding tile as a sign and pathway for the blind to be able to access the ablution area independently. c) Handrail, the presence of handrail will greatly help the blind as a guide, and support for the safety of the blind. The blind recommend that the handrail be attached to the intended area. d) Material, the use of floor material should be considered so that the visually impaired does not stumble or slip when walking. e) Floor elevation, minimizing the amount of floor elevation differences so that the blind does not stumble easily when stepping. f) Place/shelf of goods, its existence is needed to place luggage or religious equipment so it does not interfere with ablution activities.

The results of simulations and interviews with people who are crutch users and researchers as if crutch users raise several complaints and needs. The following are suggestions from respondent $B$ and researchers: a) Ramp, the slope of the ramp should be considered for crutch users because if the ramp matches the disability standard, the crutch user will choose to access ramp when compared to the stairs. b) Material, the selection of floor surface material should be considered so that when the crutches/sticks tread the floor the crutches do not slip or trip over the floor material. c) Handrail, this fixture is considered for crutch users to be able to help strengthen the pedestal of the crutches used, to avoid things that are not desirable (accident). d) Spatial information, the placement of spatial information should be accessible by sight so that it is easily read, spatial information should be placed near the entrances. e) Chair, when the footstool is not strong then ablution in a sitting position is a solution because crutches can be placed first. f) Place/shelf of goods, an additional proposal in the form of a place to put luggage so it does not interfere when performing ablution.

The results of simulations and interviews with physically disabled wheelchair users 
and researchers as if those wheelchair users raised several complaints and needs. Following are suggestions from respondent $\mathrm{C}$ and researchers: a) Ramp, the slope of ramp should be considered for wheelchair users so that wheelchair users can independently access it. b) Material, the selection of material should be considered so that the wheels of the wheelchair do not slip easily and also do not prevent the wheels from moving. c) Faucets, flexible faucets are considered so that the disabled can wash parts of the body far from the faucet position. d) Grill (drainage), it is better to be parallel to the floor of the ablution room so that wheelchair users from wheelchairs can be more close to reach ablution faucets.

It was concluded that several elements that affect the accessibility of disabled people in the ablution area are as follows: ramp, steering tile, handrail, room information, stairs, ablution chairs, flexible faucets, grills, floor material, footrests, and places/shelves of goods. The proposed design of the simulation process can be seen in Table 1.

\section{Expert Interview}

The involvement of experts (architects) who already have a license from the Indonesian Architects Association with the Associate Architect classification, aims to avoid unilateral use of researchers and provide input to the proposed design of the simulation results. Sulistio Budi Wibowo, ST., MT., IAI (expert 1) was chosen on the basis of having been certified Associate Architect and has a company named as CV. Acreon Indonesia who works in the field of architectural services, as well as in practice which has handled several projects related to the mosque place of worship. Ir. Suparwoko, MURP., Ph.D., IAI (expert 2) was chosen with the consideration in addition for having been certified as Associate Architect and has a company named as PT. Archi Link Consultant who works in the field of architectural services, expert 2 is the author of a book relating to ablution places with the title "Design Standards for Ablution Places and Mosque Spatial Planning" which is very related to the research topic.

The results of the proposed design of the simulation process after going through the expert interview process resulted in several evaluations and design improvements, the results of the improvement of some of these elements can be seen in Table 1. 


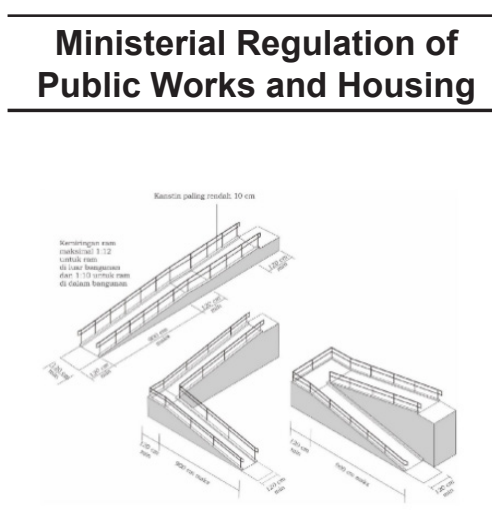

Ramp, it has been explained in the regulations regarding slope not more than $6^{\circ}$, maximum $1: 10$ for inside the building, and $1: 12$ for outside the building. The maximum ramp length is 9 meters, which if it exceeds, border is needed to divide the length of the ramp.
Simulation

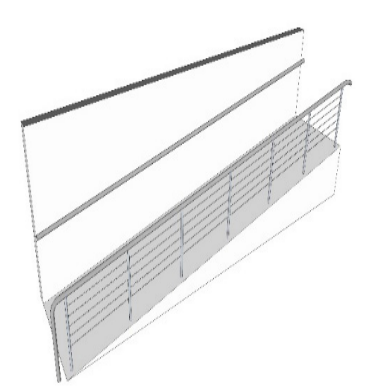

The simulation results show a The results of discussions with ramp design with a slope of $6^{\circ}$ experts resulted in the addition that is equipped with a handle of canstein at the edge of the (handrail) and a guiding block. ramp with a minimum height of $10 \mathrm{~cm}$, so that the ramp is more safely accessed and the visually impaired can easily detect canstein as the limit of ramp.

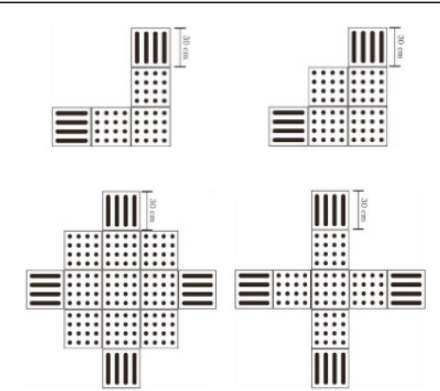

Steering Tiles, explained in regulations related to arrangements for turns, junctions, and other warning signs such as the beginning and end of stairs and ramp, and others. The steering tile has been set with a size of road orders. $30 \times 30 \mathrm{~cm}$

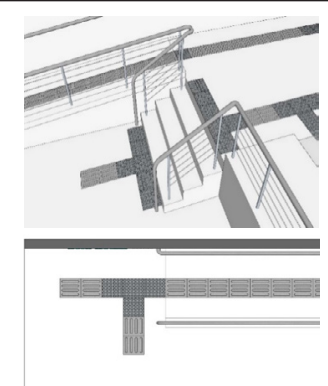

The simulation results show The results of the discussion the arrangement of round/ with the experts agreed on the point texture tiles as warning arrangement of the referring signs arranged at turns, tiles. The tiles are intended intersections, and other for the visually impaired to warning signs. Tile texture facilitate directing and guiding lines as directional signs or the blind.

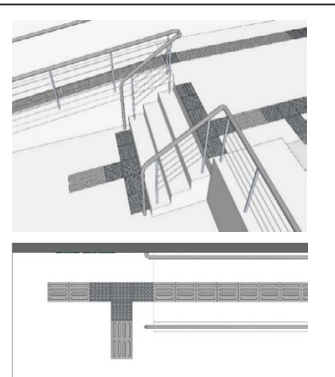




\section{Ministerial Regulation of} Public Works and Housing
Simulation
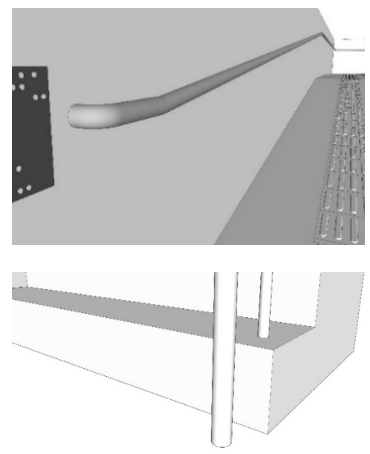

Expert Interview

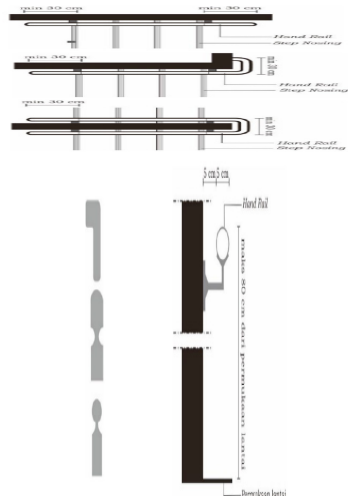

Handrail, explained in The simulation results show The results of discussions regulations related to height, that there are 2 designs of with experts produce handrail clear distance from the the handrail, one on the wall design input that is extended at wall, and distance from the and one directly on the floor. least $30 \mathrm{~cm}$ from the beginning beginning and end of the stairs or ramp. The position of the handrail in the place of special ablution of the disabled is also described in a visible image.

\section{The height is $65-80 \mathrm{~cm}$.}

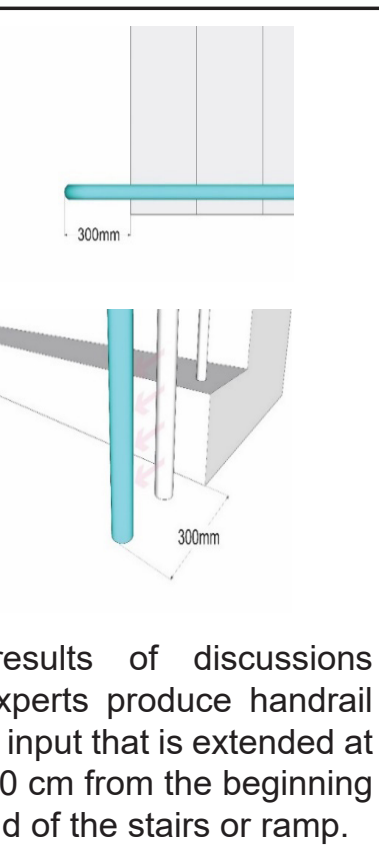

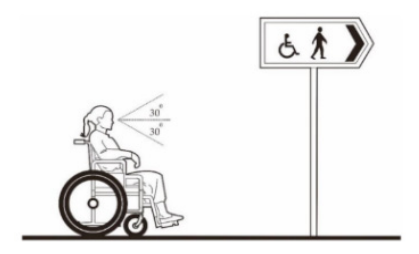

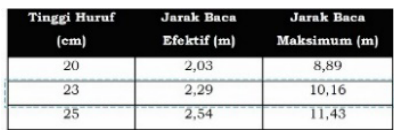

\section{Spatial information,} explained in regulations in the form of signs and markings as well as ideal distances for reading a letter, and information for the disabled are explained in the form of braille letters. However, the position of information space to direct to the area of ablution has not been explained in detail in the regulations. 


Ministerial Regulation of Simulation
Public Works and Housing

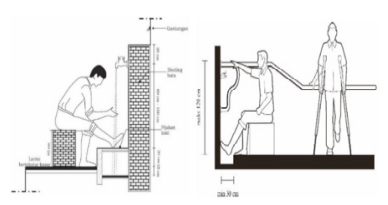

(Figure source: Suparwoko, 2016)

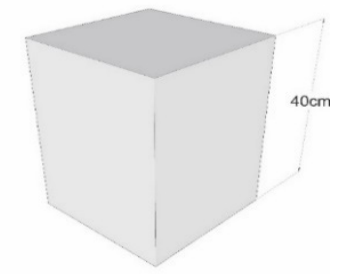
is interference with the footstool when standing, however, other disabled people can use it.

Chair, explained in the The simulation results produce The results of the experts' regulations in the image a chair design with a height of discussion resulted in shown in the area of ablution, $40 \mathrm{~cm}$ and a width of $30 \times 30 \mathrm{~cm}$. evaluations related to the explanation only related Chairs are needed by crutch design of the chair that is to the ablution chair with a users especially because there changing the area of the chair,

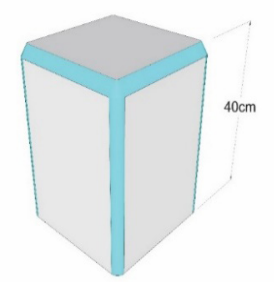
height of $40 \mathrm{~cm}$.

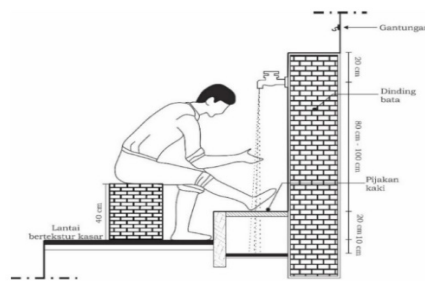

(Figure source: Suparwoko, 2016)

Faucet, explained in the regulations regarding the position of the height of the faucet and the distance between the faucets, however, it has not been explained in detail related to the type of faucets that are easy to use by the disabled.

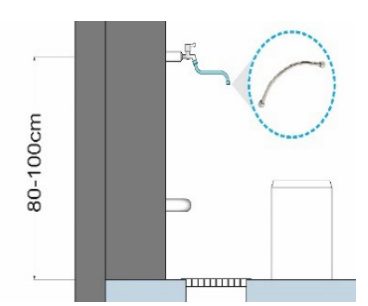

The simulation results produce a proposal for the use of a flexible type of faucet to simplify and expand the flush reach of simplify and expand the flush the ablution faucet, especially reach of the ablution faucet, for the ablution disabled in a not difficult when going to sitting position. wash the body parts far from the faucet. 


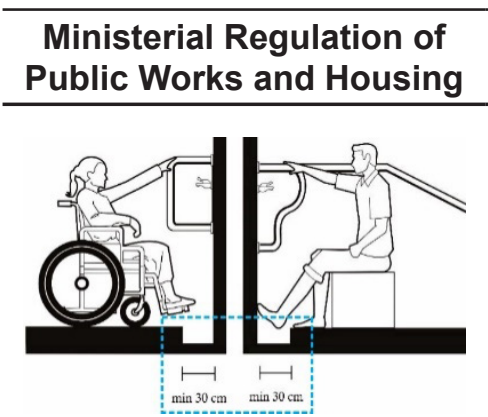

Grill, explained in the regulations, is only a visible image that explains the width of the grill, that is, a minimum of $30 \mathrm{~cm}$. However, in detail it has not yet explained how it relates to the process of ablution for the disabled.
Simulation

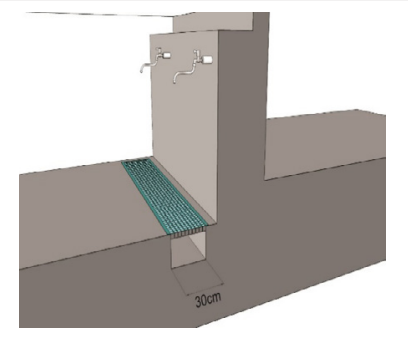

The simulation results in a proposed grill design that has a flat surface with the ablution room floor, so that the wheel of the wheelchair can be more advanced to reach the ablution faucet. The grill is also considered so that the wheels of the wheelchair are not stuck.
"Ablution room floor must use coarse-textured material, not slippery and easy to clean."

Material, which has been The

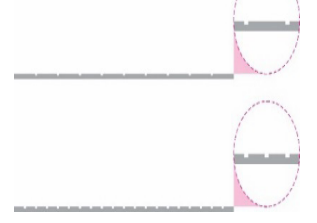

simulation process generates proposals related to the need for non-slippery material or textured material, so that it does not slip easily when performing ablution due to a wet floor.

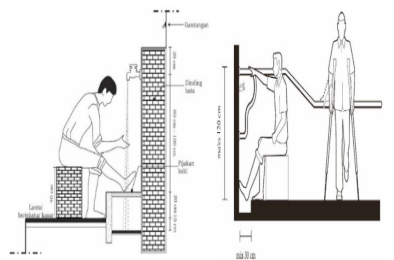

Footrest, has been described in one of the pictures there is a grill that functions as a footrest. However, in the picture where the ablution is specifically for disabled, it is not explained its existence.

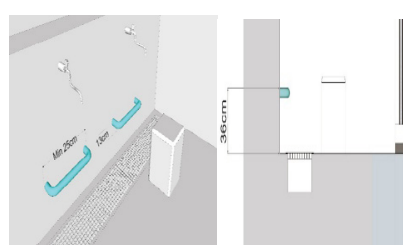

The simulation results produce a footrest design proposal that is needed to make it easier when washing the feet, especially for the disabled who are doing ablution in a sitting position.

\section{Expert Interview}

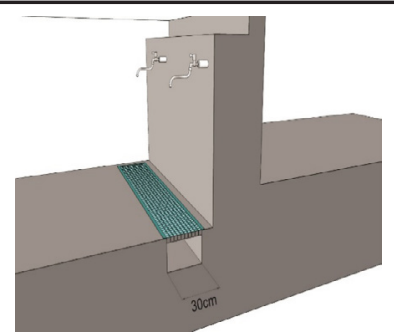

The results of the experts' discussion agreed on the design of the grill should be flat on the floor of the ablution room, so that wheelchair users could freely access the ablution faucet. not slippery, and easy to clean.
The results of the experts' discussion agreed on the use of non-slippery or textured material, in order to reduce slipperiness on the floor.
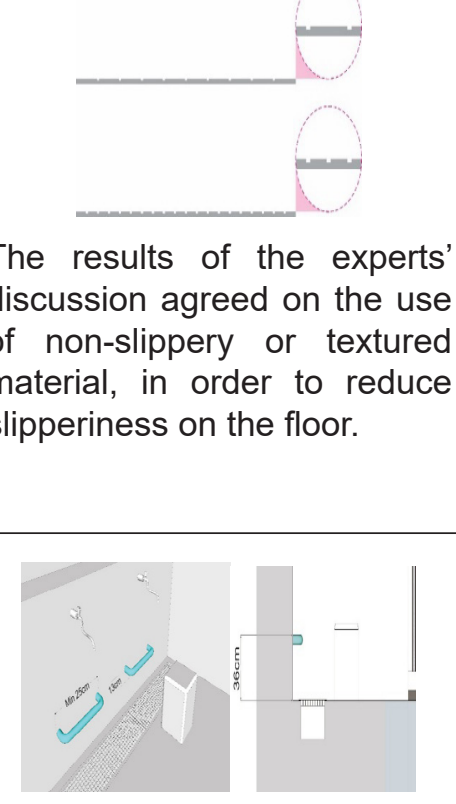

The results of the experts' discussion agreed on the design of footrests, in order to make it easier when washing the legs, especially for the disabled who performs ablution in a sitting position, in line with Suhardi's research in the journal of Design of Ablution Place for the Elderly. 


Ministerial Regulation of
Public Works and Housing

\section{Conclusion and Recommendation}

It was concluded from the simulation process several elements that affect the accessibility of disabled in the ablution area, including ramp, steering tiles, handrail, information space, stairs, ablution chairs, faucets, grills, floor surface material, footrests, and places/shelves of goods. These elements are needed so that the disabled can independently access the ablution area.

Expert discussions (Architects) resulted in suggestions for improvement in several elements, such as ramp with the addition of canstein on the edge of the ramp, extended handrails at the beginning and end of the stairs, step nosing, and the ablution chair changes in the form of sharp edges to more round arches. While the elements that have not changed or have been approved by experts, namely, directing tiles, flexible faucets, grills, floor material, footrests, and places/shelves of goods.

The results of the evaluation of the Ministerial Regulation of Public Works and Housing No. $14 / 2017$ show that in general, the regulation has explained some elements that are needed by the disabled to support accessibility in the area of ablution, however, there are some elements that have not been explained in detail, which are related to the position of spatial information, ablution chairs, flexible faucets, grill that is flat with the ablution floor surface space, and footrests for the disabled with ablution in a sitting position.

\section{Recommendation}

The ablution area design recommendations have been considered with the ability of the disabled from the simulation process to the design improvement that involves experts (Architects). In addition to the ablution area, the design has also considered with the physical abilities of the elderly and has a universal design.

Figure 2. Recommended Longitudinal Space Module

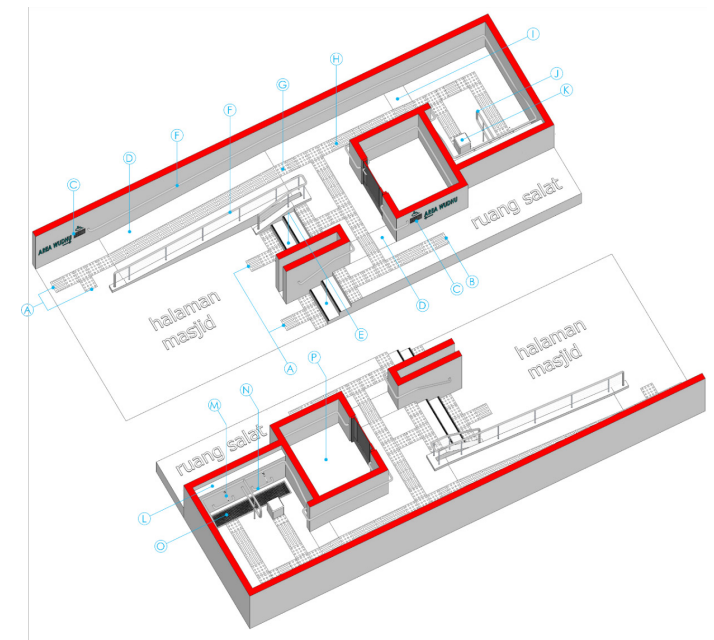


Figure 3. Recommended Short Space Module

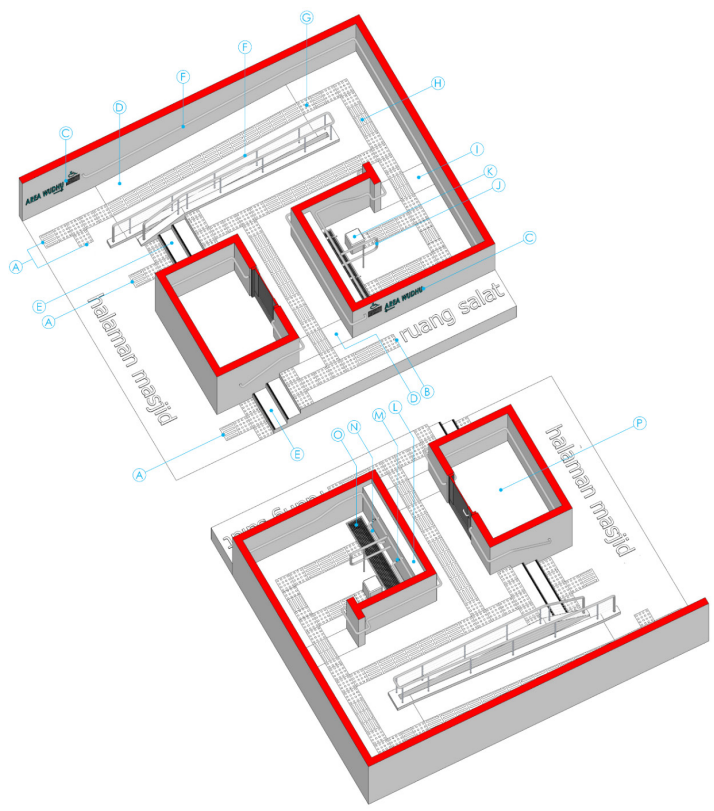

- Courtyard guide tiles, are needed to help direct the visually impaired into the ablution area. Steering tiles on the courtyard of the mosque should be connected to the steering tiles around the mosque from the pedestrian, the gate, the parking area, and other areas.

- The direction of the prayer room tiles is needed to direct the visually impaired to the ablution area from the prayer room or vice versa.

- Space information is needed to determine the existence of a space, the space information can be in the form of letters of the alphabet and letters arise (braille), which is equipped with arrows to direct and disability icons as a sign of the ablution area can be accessed by the disabled.

- Ramp, the basic need to support the mobility of people with disabilities in accessing an area with different floor elevations, from the yard and mosque area to the ablution area.

- $\quad$ Stairs, needed as an alternative to access other than ramp, stairs can be accessed by persons with visual impairments and physical impairments, crutch users, also people with normal physical access can access these stairs.

- Handrail is needed to support the security of access to the ramp, stairs, and other areas. Handrail also functions as a guide, and a holder for the disabled who experience interference in the footstool.

- Tile texture (warning blocks), tiles with dots/round textures act as warning signs or information (warning blocks), their presence is needed to inform points such as turns, junctions, ladder and ramp beginnings and endings, also other warning signs.

- Guiding block, sign or information to "go", the existence of these tiles is needed as a link between tiles with point/round texture.

- Ramp (ablution room), ablution rooms generally have different floor elevations to distinguish wet and dry areas, so that splashes or puddles do not spread to other spaces so ramp is needed to connect the two areas.

- Handrail (ablution room), the existence of the handrail in ablution room in addition to supporting the security of disabled access, handrail also functions as a medium to move when the disabled will perform ablution in a sitting position.

- Ablution chair, is needed for disabled persons with crutch, because there is interference with foot support when standing so the chair is needed for ablution in a sitting position.

- Place/shelf of goods, before performing ablution activities, a place/shelf of goods is needed so that luggage or prayer equipment such as sarong, cap, veil, and other items can be placed in advance to not interfering ablution activities.

- $\quad$ Faucet, the type of flexible faucet needed by the disabled to facilitate and expand the reach of the flush water from the ablution faucet, so that the disabled who performs ablution activity in a sitting position will not feel difficult to wash away parts of the body far from the faucet.

- Footrests are needed to make it easier for people with disabilities when washing the feet, especially for those with ablution in a sitting position. 
- Grill, the recommended grill design is a flat grill with the ablution floor surface so that the wheel of the wheelchair can be more advanced to reach the faucet, besides the grill hole is considered so that the wheel of the wheelchair is not stuck.

- Place of equipment, additional proposals for the disabled to replace their equipment such as crutches, wheelchairs, and other equipment with cleaner/holy equipment so that they can enter the prayer hall for worship.

\section{Reference}

Central Bureau of Statistics (BPS). (2010). Penduduk Menurut Wilayah dan Agama yang Dianut. Retrieved from https://sp2010. bps.go.id/index.php/site/tabel?tid=321

Direktorat Jenderal Bimbingan Masyarakat Islam. (2014). Keputusan Direktur Jenderal Bimbingan Masyarakat Islam Nomor DJ.II/802 Tahun 2014 tentang Standar Pembinaan Manajemen Masjid.

Echols, J. M., \& Hassan, S. (2014). Dictionary of English - Indonesia. Jakarta: PT. Gramedia.

Kementrian Kesehatan RI. (2014). Situasi Penyandang Disabilitas. Buletin Jendela Data \& Informasi Kesehatan. https://doi. org/10.1007/s13398-014-0173-7.2

Keumala, C. R. N. (2016). Pengaruh Konsep Desain Universal Terhadap Tingkat Kemandirian Difabel: Studi Kasus Masjid UIN Sunan Kalijaga dan Masjid Kampus Universitas Gadjah Mada. Inklusi: Journal of Disability Studies, 3(1), 19-40. https:// doi.org/10.14421/ijds.030102

Republik Indonesia. Undang-Undang Republik Indonesia Nomor 8 Tahun 2016 Tentang Penyandang Disabilitas (2016). Retrieved from http://www.kemendagri.go.id/media/ documents/2016/05/11/u/u/uu_nomor_8_ tahun_2016.pdf

Republik Indonesia. Lampiran III: Peraturan Menteri Pekerjaan Umum Dan Perumahan Rakyat Nomor 14 Tahun 2017 Tentang Persyaratan Kemudahan Bangunan Gedung (2017).

Sholihah, A. B. (2008). MOSQUE FOR ALL The Case of Yogyakarta, INDONESIA. Arsitektur Dan Teknologi Tepat Guna.

Sugiyono. (2010). Metode Penelitian Pendidikan,Pendekatan Kuantitatif dan
Kualitatif $R \& D$. Bandung: Alfabeta.

Sugiyono. (2013). Metode Penelitian Pendidikan Pendekatan Kuantitaif, Kualitatif, dan R\&D. https://doi.org/10.1016/j.tiv.2011.06.008

Sugiyono. (2014). Teknik Pengumpulan Data. In Metode Penelitian Kuantitatif, Kualitatif dan R\&D. https://doi.org/10.3354/ dao02420

Suhardi, B., Laksono, P. W., \& Saktiwan, P. (2013). Perancangan Tempat Wudhu Untuk Orang Lanjut Usia (Lansia). National Conference on Applied Ergonomics, (September).

Suparwoko. (2016). Standar Perancangan Tempat Wudhu dan Tata Ruang Masjid. https://doi.org/10.13140/ RG.2.1.3976.2000

Chapter 'Abasa verse 1-2. (n.d.). The Qur'an and Its Translation and Meaning.

Tribunnews.com. (2017). Raja Salman Terkejut Dengar Masjid di Indonesia Ada 800 Ribu. Retrieved from http://www.tribunnews.com/ nasional/2017/03/04/raja-salman-terkejutdengar-masjid-di-indonesia-800-ribu 